\title{
Development of mRNA-specific RT-PCR for the detection of koi herpesvirus (KHV) replication stage
}

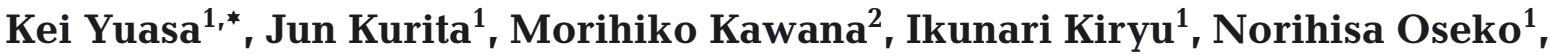 \\ Motohiko Sano ${ }^{3}$
}

\author{
${ }^{1}$ National Research Institute of Aquaculture, Fisheries Research Agency, Minamiise, Mie 516-0193, Japan \\ ${ }^{2}$ Hokkaido National Fisheries Research Institute, Fisheries Research Agency, Sapporo, Hokkaido 062-0922, Japan \\ ${ }^{3}$ National Research Institute of Fisheries Science, Fisheries Research Agency, Yokohama, Kanagawa 236-8648, Japan
}

\begin{abstract}
An mRNA-specific reverse transcription (RT)-PCR primer set spanning the exon junction of a spliced putative terminase gene in the koi herpesvirus (KHV) was developed to detect the replicating stage of the virus. The proposed RT-PCR amplified a target gene from the RNA template, but not from a DNA template extracted from common carp brain (CCB) cells infected with KHV. In addition, the RT-PCR did not amplify the target gene of templates extracted from specific cell lines infected with either CyHV-1 or CyHV-2. RT-PCR detected mRNA from the scales of koi experimentally infected with KHV at $24 \mathrm{~h}$ post exposure (hpe). However, unlike conventional PCR, RT-PCR could not detect KHV DNA in fish at 0 hpe. The results indicate that the RT-PCR developed in this study is mRNA-specific and that the assay can detect the replicating stage of KHV from both fish and cultured cells infected with the virus.
\end{abstract}

KEY WORDS: Koi herpesvirus $\cdot$ Cyprinid herpesvirus $3 \cdot$ Terminase $\cdot$ mRNA $\cdot$ RT-PCR

\section{INTRODUCTION}

All PCR methods that have been developed to date to detect cyprinid herpesvirus 3 (CyHV-3, Waltzek et al. 2005), commonly known as koi herpesvirus (KHV), are highly sensitive and specific for the virus (Gilad et al. 2002, Gray et al. 2002, Bercovier et al. 2005, Yuasa et al. 2005). Given the relative resilience of DNA to degradation, PCR assays of KHV DNA extracted from viral capsids are generally successful, even when using tissues that have started to decompose (authors' unpubl. data). However, despite being able to effectively determine the presence of KHV based on whether viral DNA was detected by PCR, the ability to assay viral mRNA is considered to be preferable, as mRNA can be used to infer whether the virus is replicating.
Avoiding genomic DNA contamination of RNA samples is essential in mRNA assays, as amplification from genomic pseudogenes, related to the sequence, and reverse-transcribed cDNA is very difficult to distinguish in some instances (Smith et al. 2001). However, it is generally very difficult to avoid genomic DNA contamination of samples without incurring some loss of RNA. In a preliminary experiment in this study, we found that DNase treatment did not fully degrade the genomic DNA template extracted from the gills of moribund fish infected with KHV.

In general, the use of primers designed in 2 exons that span an intron is an effective method for detecting viral expression genes by reverse transcription (RT)-PCR as any DNA contamination will produce 2 differently sized amplicons (1 from the genomic DNA 
and the other from the expressed gene; Smith et al. 2001). Alternatively, the use of splice-junction-spanning primers for RT-PCR can specifically amplify the target gene without amplifying any genomic DNA (Sternberg et al. 2004).

The putative ATPase subunit of terminase is one of only a few spliced genes in herpes simplex virus type 1 (HSV-1; Dolan et al. 1991). Terminase was first identified in $\lambda$ phage as the enzyme responsible for packaging viral DNA into capsids (Miwa \& Matsubara 1982). Since the terminase complex is considered to play an important role in the packaging of DNA in the herpesvirus (Yang \& Baines 2006), as well as being essential for herpesvirus multiplication (Eizuru 2005), recent studies have examined the potential for targeting the terminase complex to combat human herpesvirus. The terminase gene, which is a highly conserved (core) gene containing 2 exons, has been identified in channel catfish virus and frog herpesviruses (Davison 1992, Davison et al. 2006). In addition, complete genome analysis of KHV has shown the existence of a terminase gene that includes exon-intron structures (Aoki et al. 2007). Recently, amino acid sequences from terminase genes were analyzed to estimate the phylogenetic relationships between the herpesviruses of aquatic animals (Waltzek et al. 2009a). These studies revealed that the KHV terminase gene is conservative and includes splice junctions, which are useful targets for confirming the detection of an expressed gene.

In the present study, a primer set was designed in spliced variants of the terminase gene of $\mathrm{KHV}$ to establish an mRNA-specific RT-PCR method for detecting the replicating stage of KHV, and the sensitivity and specificity of the developed RT-PCR method were verified.

\section{MATERIALS AND METHODS}

\section{Preliminary test. DNase treatment to remove DNA from samples}

We first performed a preliminary test to determine whether DNase treatment can remove KHV DNA completely in the RNA extracts from common carp infected with KHV. Two common carp were intraperitoneally injected with $0.05 \mathrm{ml}$ of the virus stock (see 'Verification Test 5. Detection of genomic DNA and terminase mRNA of KHV-infected carp). Total DNA and RNA were extracted from carp gills sampled at 3 and $7 \mathrm{~d}$ post virus-injection (dpi) using a Puregene DNA Extraction Kit (Qiagen) and an RNeasy Mini kit (Qiagen), respectively. Numbers of KHV genome copies in $5 \mu$ l of the 2 DNA extracts were determined with real time-quantitative PCR (Gilad et al. 2004). RNA extracts were treated by incolumn digestion with DNase I (Qiagen) according to the manufacturer's instructions. Two PCR assays (Bercovier et al. 2005, Yuasa et al. 2005) were performed with $1 \mu \mathrm{l}$ of each DNase-treated RNA extract to confirm removal of DNA.

\section{Primer design}

A gene map of the putative, spliced KHV terminase gene and the sites of the primers used in this study are shown in Fig. 1. The KHV terminase gene consists of 3 exons (Aoki et al. 2007). The mRNAspecific RT-PCR primer set A (a splice junctionannealing primer set) was designed, consisting of a forward primer (KHVRT F3: 5'GGC ATC GAC ATC ATG GTG CA'3) annealing to a splice junc-

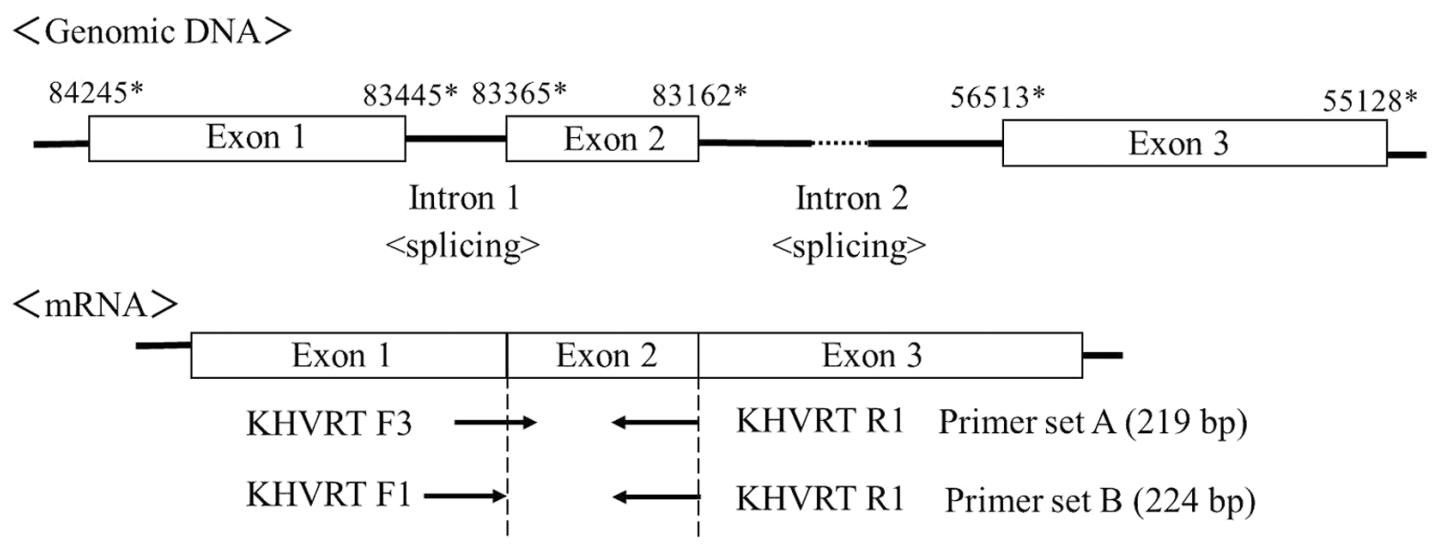

Fig. 1. Structure of the splicing sites in the putative koi herpesvirus (KHV) terminase (Aoki et al. 2007) and the position of the 6 primer sets used in this study. (*) First and terminal positions of bases in 3 exons of KHV GenBank accession no.: DQ657948 
tion located between Exons 1 and 2 and a reverse primer (KHVRT R1: 5'ATT GCC GCT GGA AGC CAG GT'3) annealing at the end of Exon 2. In addition, primer set $\mathrm{B}$ (an intron-spanning primer set) composed of another forward primer (KHVRT F1: 5'TCA TGG GCA TCG ACA TCA TG'3) annealing at the end of Exon 1 and KHVRT R1, was designed to differentially detect the presence of both genomic DNA and mRNA in templates used in this study.

\section{Verification Test 1. mRNA specificity of RT-PCR with the splice junction-annealing primer set $\mathrm{A}$}

The specificity of the RT-PCR assay for detecting the putative KHV terminase mRNA was assessed using primer sets $\mathrm{A}$ and $\mathrm{B}$ and 3 templates. To prepare the templates, the virus (NRIA0308) isolated from a wild-caught, common carp in Japan was propagated in common carp brain cells (common carp brain [CCB] cells: Neukirch \& Kunz 2001) using minimum essential medium (MEM) supplemented with $5 \%$ fetal bovine serum (FBS) in a $25 \mathrm{~cm}^{2}$ culture flask at $20^{\circ} \mathrm{C}$. At $7 \mathrm{~d}$ after inoculation of the virus, when an initial stage of the cytopathic effect (CPE), i.e. the vacuolation of cytoplasm, was observed, the cells were peeled with trypsin and collected in 2 microtubes for DNA or RNA extraction. Template 1 (total RNA with a low level of DNA contamination) was prepared by extraction from the KHV-infected cells in 1 of the tubes using TRIzol reagent (Invitrogen) and no DNase treatment. Template 2 (total RNA with a high level of DNA contamination) was prepared from a 1:9 mixture in volume of Template 1 with total DNA extracted from the infected cells in another tube using a Puregene DNA Extraction Kit (Qiagen). Template 3 was the total DNA, but treated with RNase (RNase-treated DNA). RT-PCR was performed using $2 \mu \mathrm{l}$ of these 3 templates and $23 \mu \mathrm{l}$ of the SuperScriptTM III One-Step RT-PCR system with Platinum Taq (Invitrogen). The thermal profile consisted of $55^{\circ} \mathrm{C}$ for $30 \mathrm{~min}$, with inactivation of RT at $94^{\circ} \mathrm{C}$ for 2 min followed by 35 cycles of denaturation at $94^{\circ} \mathrm{C}$ at $30 \mathrm{~s}$, annealing at $60^{\circ} \mathrm{C}$ for $30 \mathrm{~s}$, and elongation at $72^{\circ} \mathrm{C}$ for $30 \mathrm{~s}$ followed by a final elongation step of $72^{\circ} \mathrm{C}$ for $7 \mathrm{~min}$. In addition to RT-PCR, PCR with primer set $\mathrm{A}$ in which the $\mathrm{RT}$ reaction $\left(55^{\circ} \mathrm{C}\right.$ for $30 \mathrm{~min}$ ) was omitted was performed to confirm whether the origin of amplicons in RT-PCR was mRNA. Primer set $B$, using the same reaction conditions as primer set A above, was used to confirm the presence of KHV DNA template.

\section{Verification Test 2. mRNA from several KHV isolates}

The mRNA of $5 \mathrm{KHV}$ isolates was amplified by RTPCR with primer set $A_{\text {; }}$ an American isolate (KHV-U) and an Israeli isolate (KHV-I) were provided by Dr. R. P. Hedrick of California University, and 3 domestic isolates (NRIA0301, NRIA837, and NRIA962) were obtained from infected, wild carp caught in Japan in 2003, 2006, and 2007, respectively. Total RNA of each isolate was extracted from CCB cells in a $25 \mathrm{~cm}^{2}$ flask at 4 to $7 \mathrm{dpi}$ when the CPE was observed as mentioned in Test 1. The extraction method, RT-PCR reaction conditions, and thermal profile were the same as that described above.

\section{Verification Test 3. RT-PCR specificity for CyHV-3}

To verify the specificity of the RT-PCR assay for CyHV-3, 2 additional cyprinid herpesvirus isolates were also analyzed: CyHV-1 from carp and CyHV-2 from goldfish. Both isolates were provided by Dr. H. Fukuda of Tokyo Marine Science and Technology University. CyHV-1 and CyHV-2 were propagated at $20^{\circ} \mathrm{C}$ in koi fin-1 cells (KF-1: Hedrick et al. 2000) and goldfish fin cells (GFF: provided by Dr. H. Fukuda), respectively. When both cells partly showed a CPE, cells were collected and RNA was extracted with TRIzol. RT-PCR was conducted with primer set B, and the thermal profile was the same as that described above. To prove replication of both viruses in cells, PCR amplifying genomic DNA of both viruses was performed. For amplifying CyHV-1, PCR was performed with primer sets CHV diagnosis-F (5'GGC TAT CAC GCT GAA AGA GG3') and CHV diagnosis-R (5'CGG AGA TAA AGC TGC CTA CG3') (sequence information provided by K. Yamamoto and Dr. H. Fukuda) and a thermal protocol of 35 cycles of denaturation at $94^{\circ} \mathrm{C}$ at $30 \mathrm{~s}$, annealing at $60^{\circ} \mathrm{C}$ for $30 \mathrm{~s}$, and elongation at $72^{\circ} \mathrm{C}$ for $30 \mathrm{~s}$ followed by a final elongation step of $72^{\circ} \mathrm{C}$ for $7 \mathrm{~min}$. The protocol for amplifying CyHV-2 was according to Waltzek et al. (2009b).

\section{Verification Test 4. Optimization of the RT-PCR thermal profile}

The specificity obtained using RT temperatures of 42,50 , and $55^{\circ} \mathrm{C}$, followed by a common PCR cycling profile as described in Test 1 was also compared. The templates used were Templates 1 and 3. 
Next, RT-PCR was performed using primer set A and the same thermal profile described in Test 1, except that the PCR annealing temperatures were changed to 55,60 , and $65^{\circ} \mathrm{C}$. The templates used for these assays were 10 -fold serial dilutions $\left(10^{-2}\right.$ to $10^{-6}$ ) of the RNA extracted from KHV-infected CCB cells, diluted in RNA extracts from healthy common carp gills.

\section{Verification Test 5. Detection of genomic DNA and terminase mRNA of KHV from KHV-infected carp}

A KHV isolate (NRIA0308) was propagated in CCB cells cultured in MEM supplemented with 5\% FBS. After incubation at $20^{\circ} \mathrm{C}$ for $14 \mathrm{~d}$, the culture supernatant (virus stock) was stored at $-85^{\circ} \mathrm{C}$ until use. The virus titer of the supernatant was $10^{3.8} \mathrm{TCID}_{50} \mathrm{ml}^{-1}$ in CCB cells. Common carp (body weight: 1-2 g) were hatched from disinfected eggs of KHV-free broodstock and reared in the isolated area of the National Research Institute of Aquaculture (NRIA) with well water supply until used. Fish were exposed to a 1:10 dilution of viral stock solution in rearing water $(30 \mathrm{ml}$ virus solution in $300 \mathrm{ml}$ rearing water) for $1 \mathrm{~h}$. Fish were then rinsed twice in water and reared in a $60 \mathrm{l}$ tank with slowly circulating well water at $23^{\circ} \mathrm{C}$. Three fish were then sampled at 0,24 , and $48 \mathrm{~h}$ post exposure (hpe) and assayed for the genomic DNA and mRNA of KHV using approximately $20 \mathrm{mg}$ of fish scales. Extraction protocols used for genomic DNA and RNA were the same as those employed for the cultured cells (Test 1). Amplification of the genomic KHV DNA was performed according to Yuasa et al. (2005). RT-PCR for detecting the mRNA was conducted with primer set A using the optimal thermal protocol ( $\mathrm{RT}$ at $55^{\circ} \mathrm{C}$ for $30 \mathrm{~min}$, with inactivation of reverse transcriptase at $94^{\circ} \mathrm{C}$ for $2 \mathrm{~min}$ followed by 35 cycles of denaturation at $94^{\circ} \mathrm{C}$ at $30 \mathrm{~s}$, annealing at $60^{\circ} \mathrm{C}$ for $30 \mathrm{~s}$, and elongation at $72^{\circ} \mathrm{C}$ for $30 \mathrm{~s}$ followed by a final elongation step of $72^{\circ} \mathrm{C}$ for $7 \mathrm{~min}$ ).

\section{RESULTS}

\section{Preliminary test. DNase treatment to remove DNA from samples}

PCR products were not obtained using the PCR assays of Yuasa et al. (2005) and Bercovier et al. (2005) with DNAse-treated gill RNA extracted at 3 dpi. However, both PCR assays amplified a product of 292 or 409 bp, respectively, from DNase-treated
RNA template extracted from gills sampled at 7 dpi (Fig. 2). Numbers of KHV genome copies present in the extracted DNA template determined with the real time-quantitative PCR were $2.4 \times 10^{3}$ copies and $1.8 \times 10^{6}$ copies in $1 \mu$ l of the DNA extractions from the gills sampled at 3 and $7 \mathrm{dpi}$, respectively. This result revealed that the DNase treatment cannot completely remove KHV DNA in samples heavily infected with KHV.

\section{Verification Test 1. mRNA specificity of RT-PCR with the splice junction-annealing primer set $\mathrm{A}$}

The RT-PCR performed using the splice junctionannealing primer set $\mathrm{A}$ and Templates 1 and 2 produced a clear $219 \mathrm{bp}$ amplicon, and no false amplicons using Template 3 (RNase-treated DNA; Fig. 3a). The PCR (no RT) performed using primer set A and Templates 1, 2, and 3 produced no amplicon (Fig. 3b), indicating that the amplicons obtained by the RTPCR with primer set A originated from mRNA template. The RT-PCR performed using the intron-spanning primer set $\mathrm{B}$ and 3 templates indicated the presence of mRNA (224 bp in amplicon size) in Templates 1 and 2, and the presence of genomic DNA (303 bp in amplicon size) in all templates (Fig. 3c).

\section{Verification Test 2. mRNA from several KHV isolates}

The RT-PCR performed using primer set A detected mRNA of KHV terminase in extracts from CCB cells infected with all of the KHV isolates assayed (Fig. 4).

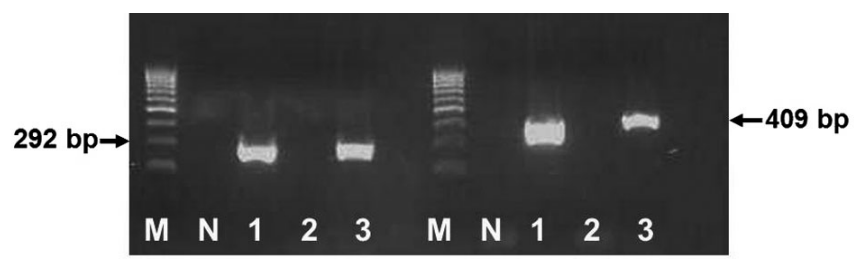

Fig. 2. Products of 2 PCR assays targeted against koi herpesvirus (KHV) DNA template: Yuasa et al. (2005) (292 bp) and Bercovier et al. (2005) (409 bp). Lane M: marker. Lane N indicates the result of a PCR with a negative template (distilled water). Lane 1: amplicons produced using DNA extract from the gills of fish sampled at $7 \mathrm{~d}$ post infection (dpi). Lane 2: amplicons produced using DNase-treated RNA extract from the gills of fish sampled at $3 \mathrm{dpi}$. Lane 3: amplicons produced using DNase-treated RNA extract from the gills of fish sampled at $7 \mathrm{dpi}$. Note that both PCR assays can amplify KHV DNA in DNase-treated RNA extract from the gills of fish sampled at $7 \mathrm{dpi}$ 

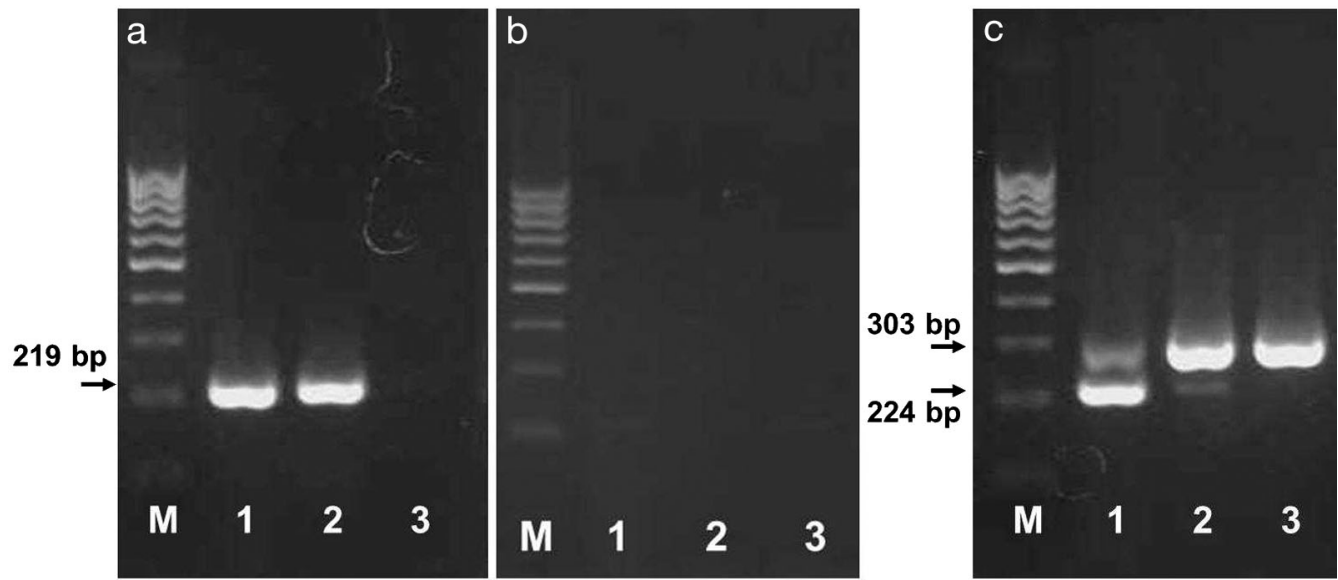

Fig. 3. Products produced by (a) RT-PCR or by (b) PCR with primer set A, and by (c) RT-PCR with primer set B. Bands in Lanes 1,2 , and 3 indicate the amplicons produced using Template 1 (RNA extracted from koi herpesvirus [KHV]-infected common carp brain [CCB] cells), Template 2 (mixture of Template 1 and DNA extracted from KHV-infected CCB cells), and Template 3

(DNA extracted from KHV-infected CCB cells treated with RNase). Marker (M) indicates 100, 200,...1000 bp

This result indicates that RT-PCR with primer set A can produce a target amplicon from several KHV strains from widely different geographical areas.

\section{Verification Test 3. RT-PCR specificity for CyHV-3}

Cells infected with CyHV-1 and CyHV-2 in culture flasks initially showed CPE at 7 and $10 \mathrm{dpi}$, respectively, indicating viral replication, and were used for Test 4.

RT-PCR performed using primer set A did not produce any amplicons when used with RNA extracted from either CyHV-1- or CyHV-2-infected cells in these flasks, although PCR performed using primer sets specific for amplifying CyHV-1 and CyHV-2 DNA showed a single clear band at 433 and 366 bp in gels, respectively (Fig. 5), confirming the presence of the viral species in the target template. This indicates

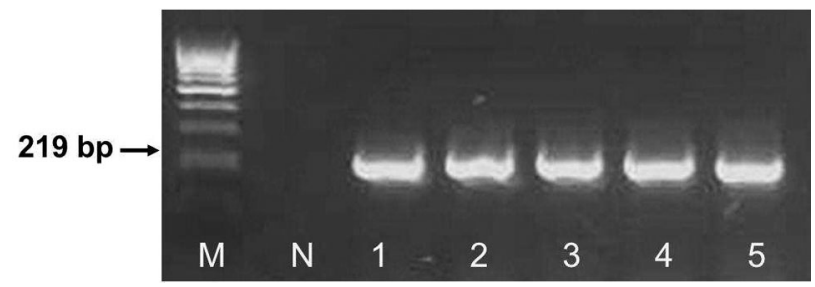

Fig. 4. Amplification products obtained from common carp brain cells infected with different isolates of koi herpesvirus (KHV). RT-PCR with primer set A using a standard protocol was conducted. Bands in Lane 1, 2, 3, 4, and 5 indicate successful amplification of all 5 isolates, KHV-I, KHV-U, NRIA0301, NRIA0610, and NRIA0710, respectively. Lane $\mathrm{M}$ : marker. Lane $\mathrm{N}$ indicates the result of RT-PCR with a negative template (distilled water) that primer set A is specific to CyHV-3 among cyprinid herpesviruses.

\section{Verification Test 4. Optimization of the RT-PCR thermal profile}

RT-PCR performed using Template 1 (total RNA) and primer set $\mathrm{A}$ and $\mathrm{RT}$ at 42,50 , and $55^{\circ} \mathrm{C}$ produced a single amplicon of $219 \mathrm{bp}$ for each temperature. RT-PCR performed using Template 3 (RNasetreated DNA) and primer set A and RT at $42^{\circ} \mathrm{C}$ produced a false amplicon with a size close to that of

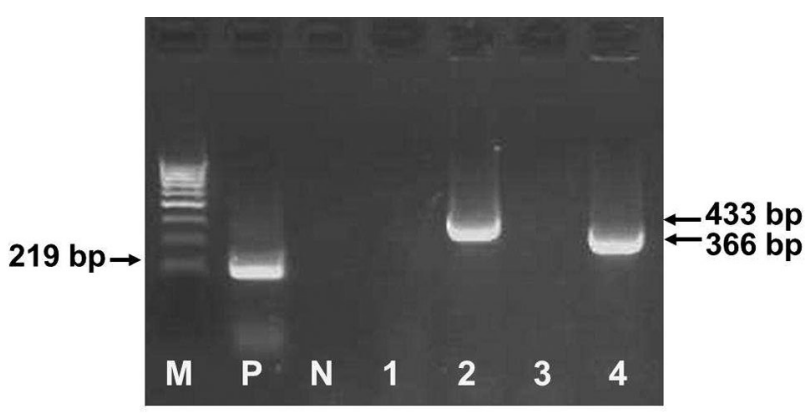

Fig. 5. Results of RT-PCR with primer set A and RNA template from common carp brain (CCB) cells infected with CyHV-1 (Lane 1) and goldfish fin cells (GFF) cells infected with CyHV-2 (Lane 3). Results of PCR with a CyHV-1specific primer set and DNA template from the CCB cells (Lane 2) and with a CyHV-2-specific primer set and DNA template from the GFF cells (Lane 4) are also shown. Note that CyHV-1 and CyHV-2 DNA could be detected by CyHV1- and CyHV-2-specific PCR (Lanes 2 and 4), confirming virus presence in the cells. Lane $\mathrm{M}$ : marker. Lanes $\mathrm{P}$ and $\mathrm{N}$ indicate the results of RT-PCR with positive (for primer set A) and negative templates, respectively 
the 219 bp expected for the product (Lane 2 in Fig. 6), but not at 50 or $55^{\circ} \mathrm{C}$.

Non-specific bands were observed using Template 1 in RT-PCR reactions (RT at $55^{\circ} \mathrm{C}$ ) with an annealing temperature of $55^{\circ} \mathrm{C}$, but not when RT-PCR reactions had an annealing temperature of 60 or $65^{\circ} \mathrm{C}$. The sensitivity of the RT-PCR for detecting mRNA was the same at all temperatures when extracted RNA samples were diluted from $10^{-2}$ to $10^{-5}$ (Fig. 7).

\section{Verification Test 5. Detection of genomic DNA and terminase mRNA of KHV from KHV-infected carp and CCB cells}

KHV genomic DNA was detected in KHV-exposed carp at 0,24 , and 48 hpe. In addition, KHV terminase mRNA was detected in these carp at 24 and 48 hpe, but not at 0 hpe (Fig. 8). The result indicates that $\mathrm{KHV}$ which adhered on the fish skin at 0 hpe was not replicating.

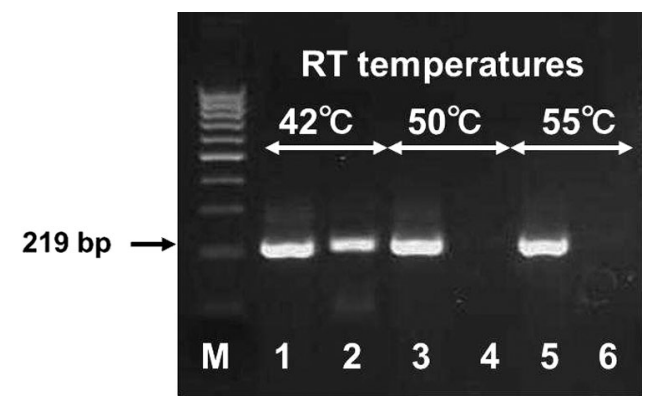

Fig. 6. Products of RT-PCR produced using primer set A and reverse transcription temperatures of 42,50 , and $55^{\circ} \mathrm{C}$. Bands in Lanes 1, 3, 5 and 2, 4, 6 are amplicons produced using Templates 1 (total RNA) and 3 (RNase-treated DNA), respectively. Lane $\mathrm{M}$ : marker

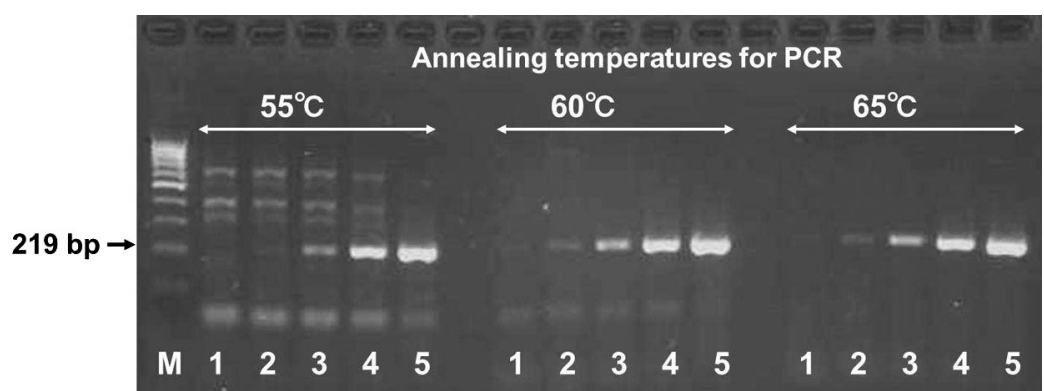

Fig. 7. Products obtained by RT-PCR using primer set A and annealing temperatures of 55,60 , and $65^{\circ} \mathrm{C}$. Bands in Lanes $1,2,3,4$, and 5 are amplicons of $1 \times 10^{-6}, 10^{-5}, 10^{-4}, 10^{-3}$, and $10^{-2}$ dilutions of RNA extracts obtained from koi herpesvirus-infected common carp brain cells. Note that extra bands were produced with an annealing temperature of $55^{\circ} \mathrm{C}$, but not at 60 and $65^{\circ} \mathrm{C}$. Lane M: marker

\section{DISCUSSION}

RT-PCR is a commonly used technique for detecting gene expression. Although the treatment of RNA samples with DNase is used for reducing potential amplification of contaminating genomic DNA, our results indicated that digestion of DNA in the DNase treatment can be incomplete for DNA of virusinfected samples containing a high number of genome copies. Furthermore, DNase treatment may result in the loss of some RNA (Harper et al. 2003). Taken together, these factors mean that treating the extracted RNA with DNase is not well suited for detecting low levels of RNA. Our study showed that RTPCR using primers with binding sites in splice junctions of the terminase gene could be used to amplify the mRNA but not genomic DNA in both cultured cells and fish tissues infected with KHV. Primer set A (KHVRT F3/R1), which anneals to the splice junction of Exon 1-Exon 2 amplified only the sequence of mRNA when RT was performed with temperatures above $50^{\circ} \mathrm{C}$. According to the manufacturer's instructions as well as the verification in this study, RT should be performed at $55^{\circ} \mathrm{C}$. This study demonstrated that the RT-PCR using primer set A and an optimized thermal protocol (RT at $55^{\circ} \mathrm{C}$ and annealing in PCR at 60 to $65^{\circ} \mathrm{C}$ ) can detect replicating virus in samples with high sensitivity and specificity.

In general, template targets for amplification in PCR should be single to avoid competition for reaction resources. Therefore, the RT-PCR results obtained using primer set A, which produced only 1 amplicon, is considered to be preferable to the results obtained with primer set B, which amplified 2 targets (Fig. 3). Based on this hypothesis, we focused on optimization and verification of the RT-PCR using primer set A in this study. Although it is convenient to use the RTPCR primer set A to find a single band indicating mRNA, RT-PCR using primer set $\mathrm{B}$ can detect both mRNA and genomic DNA at the same time. The choice of primer set A or B may be dependent on whether both replicating virus and genomic DNA or only replicating virus must be detected.

In addition, while RT-PCR using primer set A, developed in this study, detected the mRNA of the KHV isolates tested, it did not detect mRNAs of CyHV-1 or CyHV-2, which are related to KHV (Waltzek et al. 2009a). Therefore, this RT-PCR could be used to detect the mRNA of KHV in samples 


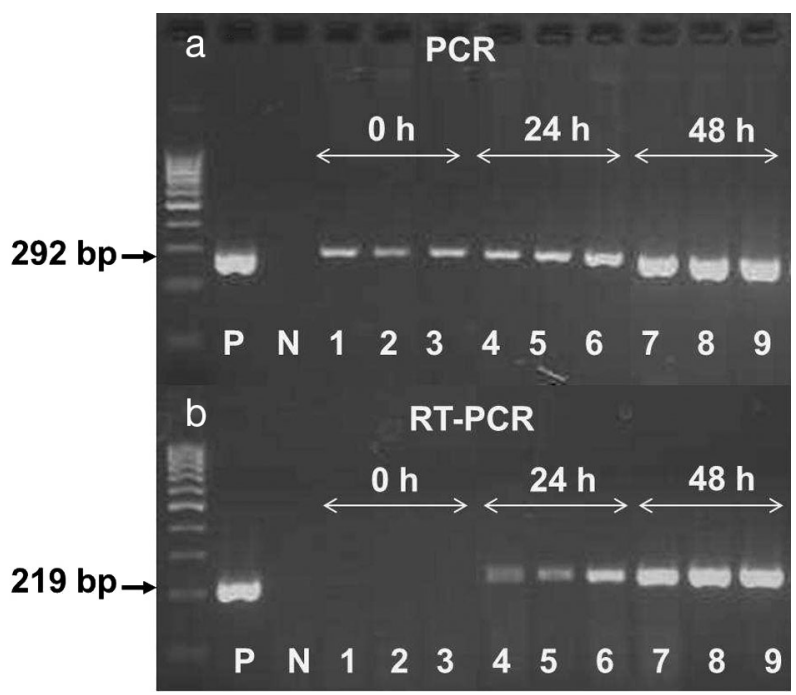

Fig. 8. Detection of koi herpesvirus (KHV) (a) genomic DNA and (b) mRNA isolated from the scales of koi exposed to $\mathrm{KHV}$ at 0,24 , and $48 \mathrm{~h}$ post virus-exposure (hpe). Lanes 1 to 3 are amplicons from 3 fish at 0 hpe, Lanes 4 to 6 are amplicons from 3 fish at $24 \mathrm{hpe}$, and bands in Lanes 7 to 9 are amplicons from 3 fish at $48 \mathrm{hpe}$. Lane P: positive controls - (a) PCR product with DNA extract from the gills of moribund carp with KHV infection and (b) RT-PCR product with RNA extract. Lane N: negative controls (with distilled water)

where there is a mixed infection of KHV and CyHV1/CyHV-2.

Selection of the optimal annealing temperature is central to increasing the specificity of any PCR assay (Yuasa et al. 2005). In our study, high PCR annealing temperatures of 60 or $65^{\circ} \mathrm{C}$, higher than the Tm, were employed in the RT-PCR to reduce the amplification of nonspecific products.

Since genomic DNA is comparatively more stable than mRNA at room temperature, a PCR assay for detecting KHV genomic DNA has certain advantages for diagnosing KHV-infected fish. Genomic DNA can easily be amplified by PCR, even from tissue samples that have begun to decay after storage at room temperature for $1 \mathrm{wk}$ (authors' unpubl. data), demonstrating the stability of the KHV genome in tissue samples. Although the RT-PCR developed in this study may be less suitable for diagnosis of KHV infection due to the unstable nature of mRNA in fish tissues, the assay targets mRNA and can be used to specifically detect the replicating stage of the virus. A PCR assay for genomic DNA was able to identify $\mathrm{KHV}$ in fish tissues as soon as 0 hpe. On the other hand, RT-PCR detected KHV mRNA in fish tissues at 24 hpe, but not at 0 hpe when the infectious virus particles had just adhered to the fish. Recently, KHV genomic DNA has been detected in body surfaces of healthy goldfish maintained together with koi that had been experimentally and naturally infected with KHV (El-Matbouli et al. 2007, Sadler et al. 2008). More recently, El-Matbouli \& Soliman (2011) suggested that goldfish are susceptible to KHV based on their result that confirmed virus replication in fish by RT-PCR with RNA templates treated with DNase. Their assay was not designed against splice junctions, nor did it consist of an intron-spanning primer set, relying only on DNase treatment to ensure specific amplification of RNA. However, a preliminary test in our study revealed that DNase treatment does not necessarily remove all DNA when present in high amounts. In addition, several researchers have not been able to demonstrate that goldfish disseminate the disease (Ilouze et al. 2011). The high reliability with which RT-PCR can detect replicating virus means that the assay may be useful for confirming whether KHV can replicate in goldfish.

Numerous studies on latent infection of human herpesviruses have been conducted to date. The latency-associated transcript (LAT), which plays a role in inhibiting apoptosis and maintaining latency by promoting the survival of infected neurons, has been detected in HSV-1 (Perng et al. 2000). However, few reports have been conducted on latent infection of herpesvirus in aquatic animals, although it has been suggested that carp surviving KHV infection may become a carrier of the virus (St-Hilaire et al. 2005, Dishon et al. 2007). Currently, we are studying the state of the virus in the main internal organs of carp surviving KHV infection. Since the RT-PCR assay developed in this study to target KHV mRNA can determine whether the virus is replicating in the organs, the method can be used to study the status of KHV in moribund and surviving fish after KHV infection.

Acknowledgements. This study was supported by grants from the Ministry of Agriculture, Forestry, and Fisheries of Japan.

\section{LITERATURE CITED}

Aoki T, Hirono I, Kurokawa K, Fukuda H and others (2007) Genome sequence of three koi herpesvirus isolates representing the expanding distribution of an emerging disease threatening koi and common carp worldwide. J Virol 81:5058-5065

Bercovier H, Fishman Y, Nahary R, Sinai S and others (2005) Cloning of the koi herpesvirus (KHV) gene encoding thymidine kinase and its use for a highly sensitive PCR based diagnosis. BMC Microbiol 5:13

Davison AJ (1992) Channel catfish virus: a new type of herpesvirus. Virology 186:9-14 
Davison AJ, Cunningham C, Sauerbier W, McKinnell RG (2006) Genome sequences of two frog herpesviruses. J Gen Virol 87:3509-3514

Dishon A, Davidovich M, Ilouze M, Kotler M (2007) Persistence of cyprinid herpesvirus 3 in infected cultured carp cells. J Virol 81:4828-4836

Dolan A, Arbuckle M, McGeoch DJ (1991) Sequence analysis of the splice junction in the transcript of herpes simplex virus type 1 gene UL15. Virus Res 20:97-104

Eizuru Y (2005) New antivirals for herpesviruses (in Japanese). Uirusu 55:95-104

El-Matbouli M, Soliman H (2011) Transmission of Cyprinid herpesvirus-3 (CyHV-3) from goldfish to naïve common carp by cohabitation. Res Vet Sci 90:536-539

El-Matbouli M, Saleh M, Soliman H (2007) Detection of cyprinid herpesvirus type 3 in goldfish cohabiting with CyHV-3-infected koi carp (Cyprinus carpio koi). Vet Rec 161:792-793

Gilad O, Yun S, Andree KB, Adkison MA and others (2002) Initial characteristics of koi herpesvirus and development of a polymerase chain reaction assay to detect the virus in koi, Cyprinus carpio koi. Dis Aquat Org 48: 101-108

Gilad O, Yun S, Zagmutt-Vergara FJ, Leutenegger CM, Bercovier H, Hedrick RP (2004) Concentrations of a koi herpesvirus (KHV) in tissues of experimentally infected Cyprinus carpio koi as assessed by real-time TaqMan PCR. Dis Aquat Org 60:179-187

Gray WL, Mullis L, LaPatra SE, Groff JM, Goodwin A (2002) Detection of koi herpesvirus DNA in tissues of infected fish. J Fish Dis 25:171-178

Harper LV, Hilton AC, Jones AF (2003) RT-PCR for the pseudogene-free amplification of the glyceraldehyde-3phosphate dehydrogenase gene (gapd). Mol Cell Probes 17:261-265

Hedrick RP, Gilad O, Yun S, Spangenberg V (2000) A herpesvirus associated with mass mortality of juvenile and adult koi, a strain of common carp. J Aquat Anim Health 12:44-57

Ilouze M, Davidovich M, Diamant A, Kotler M, Dishon A (2011) The outbreak of carp disease caused by CyHV-3 as a model for new emerging viral diseases in aquaculture: a review. Ecol Res 26:885-892

Editorial responsibility: Catherine Collins, Aberdeen, UK
Miwa T, Matsubara K (1982) Identification of sequences necessary for packaging DNA into lambda phage heads. Gene 20:267-279

Neukirch M, Kunz U (2001) Isolation and preliminary characterization of several viruses from koi (Cyprinus carpio) suffering gill necrosis and mortality. Bull Eur Assoc Fish Pathol 21:125-135

Perng GC, Jones C, Ciacci-Zanella J, Stone M and others (2000) Virus-induced neuronal apoptosis blocked by the herpes simplex virus latency-associated transcript. Science 287:1500-1503

Sadler J, Marecaux E, Goodwin AE (2008) Detection of koi herpesvirus (CyHV-3) in goldfish, Carassius auratus (L.), exposed to infected koi. J Fish Dis 25:171-178

Smith RD, Ogden CW, Penny MA (2001) Exclusive amplification of cDNA template (EXACT) RT-PCR to avoid amplifying contaminating genomic pseudogenes. Biotechniques 31:776-778, 780, 782

St-Hilaire S, Beevers N, Way K, Le Deuff RM, Martin P, Joiner C (2005) Reactivation of koi herpesvirus infections in common carp Cyprinus carpio. Dis Aquat Org 67: $15-23$

> Sternberg LR, Byrd JC, Hansson GC, Liu KF, Bresalier RS (2004) Alternative splicing of the human MUC2 gene. Arch Biochem Biophys 421:21-33

Waltzek TB, Kelley GO, Stone DM, Way K and others (2005) Koi herpesvirus represents a third cyprinid herpesvirus (CyHV-3) in the family Herpesviridae. J Gen Virol 86: 1659-1667

Waltzek TB, Kelley GO, Alfaro ME, Kurobe T, Davison AJ, Hedrick RP (2009a) Phylogenetic relationships in the family Alloherpesviridae. Dis Aquat Org 84:179-194

> Waltzek TB, Kurobe T, Goodwin AE, Hedrick RP (2009b) Development of a polymerase chain reaction assay to detect cyprinid herpesvirus 2 in goldfish. J Aquat Anim Health 21:60-67

Yang K, Baines JD (2006) The putative terminase subunit of herpes simplex virus 1 encoded by $\mathrm{U}_{\mathrm{L}} 28$ is necessary and sufficient to mediate interaction between $\mathrm{pU}_{\mathrm{L}} 15$ and $\mathrm{pU}_{\mathrm{L}}$ 33. J Virol 80:5733-5739

Yuasa K, Sano M, Kurita J, Ito T, Iida T (2005) Improvement of a PCR method with the Sph 1-5 primer set for the detection of koi herpesvirus (KHV). Fish Pathol 40:37-39

Submitted: June 22, 2011; Accepted: May 13, 2012

Proofs received from author(s): July 20, 2012 